\title{
Design of Standalone Photovoltaics (PV) / Biogas Hybrid Power System with Hydrogen Storage: Case of Northern Nigeria
}

\author{
Ismail Abubakar Jumare 1,2 \\ ${ }^{1}$ Mechanical Engineering Department, Faculty of Technology, \\ University of Tlemcen, B.P. $119 \mid$ Pôle Chetouane, \\ Tlemcen, 13000, Algeria. \\ ${ }^{2}$ Pan African University Institute of Water and Energy Sciences (PAUWES) \\ c/o University of Tlemcen, B.P. 119| Pôle Chetouane, \\ Tlemcen, 13000, Algeria.
}

\begin{abstract}
The need for more sustainable and efficient fuel applicable to different development sectors calls for different strategies in energy systems pattern. This paper is aimed at designing off-grid solar PV/biogas hybrid power system with hydrogen storage for Maiduguri in Northern Nigeria, using HOMER and Microsoft-Excel tools. This was based on physical component techno-economic modelling and optimization coupled with energy efficiency assessment and a supplementary economic benefit evaluation of system switch over. Potential impact assessment of the hydrogen production was also ensured. The optimization result for the system with the maximum hydrogen production showed energy generation of $3,014.66 \mathrm{MWh}$, but was found to be $31 \%$ less in the energy efficiency (EE) adoption. The hydrogen production of the system being $2,768 \mathrm{~kg} / \mathrm{yr}$. increased by $5 \%$, with net present cost reduction by $39 \%$ and further greenhouse gas emissions reduction all in favour of the energy efficiency adoption to the system. The supplementary economic benefits showed a realisable payback period and other potential impacts from the saved cash in switching to the energy efficiency adoption from the based-case standalone system. The generated hydrogen revealed its sustainability impact in an analyses of transport sector. These in overall being a double-target approach could be of tremendous benefit in energy solutions.
\end{abstract}

Keywords - Hybrid clean energy system; off-grid operations; energy efficiency assessment; hydrogen potential impact assessment; sustainability

\section{INTRODUCTION}

Electricity is a fundamental requirement to the development of any nation, and a key driver to industrialization. However, the kind of electricity service to be offered is of great concern in ensuring sustainability. This therefore necessitates going for alternative energy service in a wide spread for improved benefits sustainably where all the major pillars are addressed viz. social or societal, economic, and environmental pillars of the development, while also focussing on judicious measures for efficient utilizations. It is further stated that some advantages are closely associated with the alternative or renewable energy venture, among which are environmental and climate security, opportunities for human empowerment (i.e. job creations), economic viability due to its long-term benefits, improved power quality, security and reliability etc. [1].
The storyline for the African continent has always been a critical one considering the fact that a lot of energy resources exist especially the renewables such as the abundant biomass, solar, wind, hydro and geothermal. However, harnessing the opportunities has always been a challenge. According to [2], two-third of the continent lacks modern energy service particularly in the sub-Saharan region. In the adoption of the alternative energy, chances exist in multiple resources coupling, forming a hybrid, while also addressing intermittency associated with any potential resource. The network is also a great concern, which the off-grid system is advocated for due to its less complexity and in considerations of the utility grid-challenges faced by many nations inclusive of the case study country.

The design of the hybrid energy system is usually done with many distinguishing software packages that include Hybrid Optimization of Multiple Energy Resources (HOMER), RETSCREEN, Transient System (TRNSYS), MATLAB / Simulink, System Advisor Model (SAM), Improved Hybrid Optimization by Genetic Algorithm (iHOGA) etc., enabling accurate modelling, simulations, optimization, economics, control, and so on.

Furthermore, energy storage in line with the system design is equally important in execution of the hybrid system especially on event of fluctuation of some resources or excess generation. This ensures efficiency in operation and energy wastage minimization. Many techniques including the hydrogen storage concept were reported in some details as described in table 1 .

TABLE 1. Breakdown of the Features of Energy Storage

\begin{tabular}{|c|c|c|c|c|c|}
\hline Attributes & Efficiency & Maturity & Costs & $\begin{array}{l}\text { Energy } \\
\text { Density }\end{array}$ & $\begin{array}{l}\text { Power } \\
\text { Density }\end{array}$ \\
\hline CAES & $70 \%$ & Matured & High & High & High \\
\hline PHS & $75-85 \%$ & Matured & High & $\begin{array}{l}\text { Depend } \\
\text { on } \\
\text { reservoir } \\
\text { size }\end{array}$ & $\begin{array}{l}\text { Depend } \\
\text { on } \\
\text { distance } \\
\text { between } \\
\text { reservoirs }\end{array}$ \\
\hline Hydrogen & $50-60 \%$ & $\begin{array}{l}\text { Early } \\
\text { Stage }\end{array}$ & High & $\begin{array}{l}\text { Depends } \\
\text { on } \mathrm{H}_{2} \\
\text { reservoir }\end{array}$ & $\begin{array}{l}\text { Depend } \\
\text { on speed }\end{array}$ \\
\hline
\end{tabular}




\begin{tabular}{lcccll}
\hline & & & & \\
Flywheel & $80-90 \%$ & Mature & Low & Low & $\begin{array}{l}\text { of } \\
\text { reaction }\end{array}$ \\
High & High \\
Capacitor & $80-95 \%$ & Immature & High & Low & High \\
SMES & $90-95 \%$ & Immature & High & Low & High \\
Battery & $75-85 \%$ & Matured & Low & High & High
\end{tabular}

Key: CAE: Compressed Air Energy Storage, PHS: Pumped Hydro Storage, SMES: Superconducting Magnetic Energy Storage

Based on the above brief information, many studies have been conducted hybrid power system both in Africa and beyond. Hence, focusing on the studies with the hydrogen storage, a few exist in the literature search with some of them brought forth. Douglas [3] investigated the dynamic modelling and simulation of a Solar PV hybrid battery and hydrogen energy storage system using MATLAB/Simulink for satisfying a residential load $(2.46 \mathrm{~kW}$ Peak Load) of Port Harcourt in Nigeria. A techno-economic analyses of hybrid renewable energy system for off-grid application coupled with hydrogen production has been done by Abdin and Merida [4] for different global locations. The authors considered different scenarios using solar PV, wind turbine, battery, electrolyzer, and fuel cell using HOMER software. Barakat et al. [5] did modelling of hybrid marine current-hydrogen active power generation system. Components viz. marine current turbine, electrolyzer, and fuel cell were used for power supply to the demand side with hydrogen storage and its application to fuel cell for power generation during load deficit. Finally, Groppi et al. [6] analyzed the economic and environmental sustainability of battery and hydrogen storage for augmenting the energy independence of Flavignana Island in Italy using HOMER tool. The authors used split PV components with diesel genset and battery bank for the optimum sizing and power supply to the load demand of $11.99 \mathrm{MW}$ peak, coupled with an electrolyzer for the hydrogen production.

This paper is therefore a double-benefit target, with a purpose of modelling and optimizing the hybrid PV/biogas power system with hydrogen storage for the case of Maiduguri, in Northern Nigeria. This is majorly on techno-economic and environmental measures, coupled with the impacts and benefits assessment of energy efficiency of such transition as well as the potential qualitative and quantitative benefit assessments of the hydrogen production as a secondary energy source. These tasks could be seen to have some novel aspects being a complement to the already done tasks on the integrated/combined systems design with hydrogen storage and also due to the fact that no studies combining solar PV and biogas as well as the hydrogen concept have been conducted in the site viewed with persistent energy deficits. Further novelty might be attributed to the energy efficiency analyses incorporated in the research. The basis behind choosing the system components i.e. the solar PV and biogas genset is the fact that a lot of solar resource potentials exist in the Northern region especially the North-eastern zone where the study lies, as well as the strong need to harness the abundant wastes in to useful final energy in power systems operation while also saving the environment.

\section{STUDY SITE DESCRIPTION AND RESOURCE ASSESSMENT}

On a general perspective, the country at large has 2 seasonal experiences i.e. summer season, otherwise known as the wet season that lies between April to October, and the winter season, also known as the dry season that ranges from November to March [7]. This is applicable to all states in the country however with much variations as some sites tend to experience extreme weather conditions that others. Moving to the case of study, which is Maiduguri, it is a local government of Borno state in the north-eastern part of the country. This site is also associated with extreme weather conditions as well with more of heat than cold in its weather distribution pattern. The site is located at an elevation of $325 \mathrm{~m}$ above sea level, with a coordinate of $11.8311^{\circ} \mathrm{N}$ and $13.1510^{\circ} \mathrm{E}$ [8]. This site is among the sites with low electricity access having seen on the regional/zonal electrification rate statistics of the country. Most households rely on diesel and gasoline genset in addressing their energy needs, which is proved with negative consequences, hence, requiring a better alternative of such nature, where it will serve as a double benefit target.

On moving to the resource information of the study site, it is obvious the existence of abundant solar resource and high wind resource to some extent. The only considered climate data applicable to the power system modelling is the solar resource data with the accompanied air temperature. These have been brought forth in the subsequent figures beginning with the weather distribution pattern. (see figures 1,2 and 3)

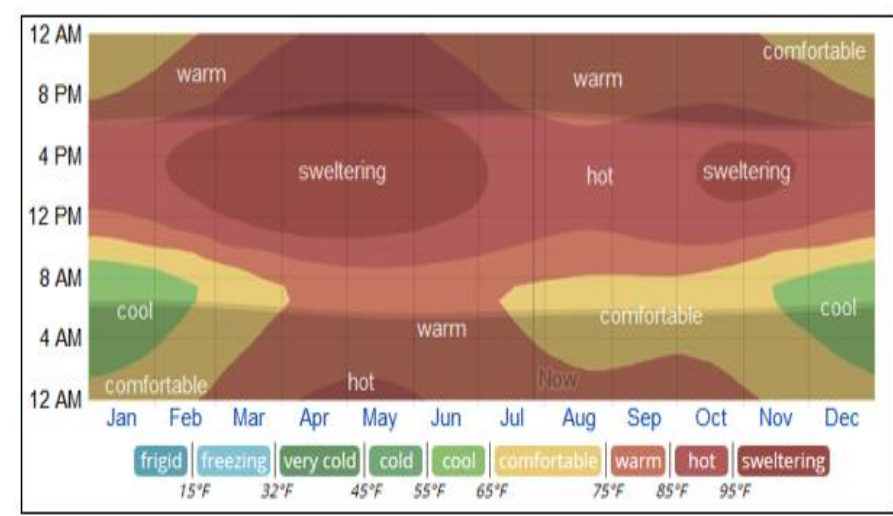

Fig. 1: Average hourly temperature with weather pattern distribution in the

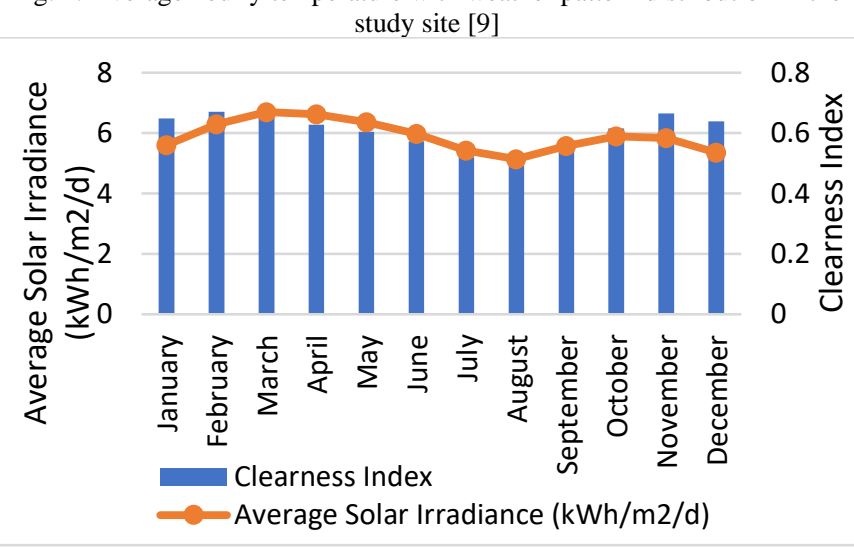

Fig. 2. Solar irradiance data and associated clearness index in the study site [10] 


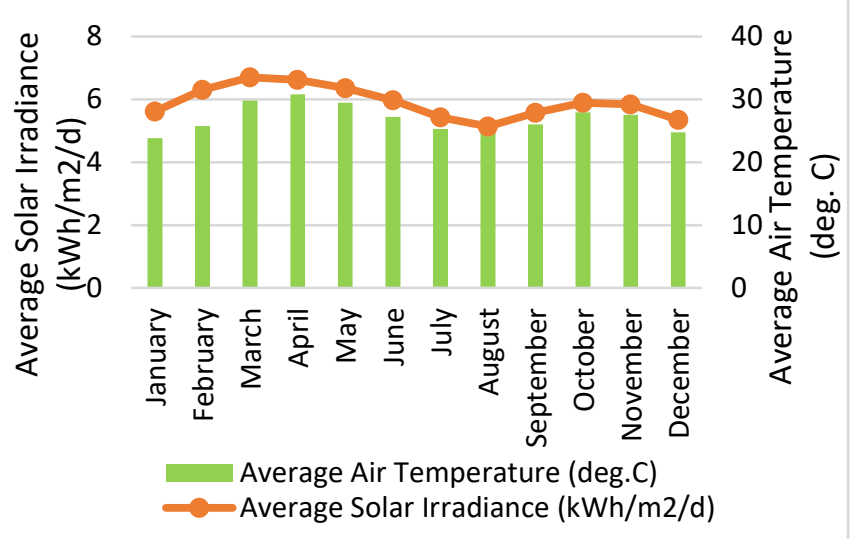

Fig. 3. Solar irradiance data and associated air temperature in the study site [10]
Biomass resources on the other hand, basing on vegetation is considered sparsely available, and not taken in to considerations. However, waste biomass resources especially animal wastes are largely available everywhere in the country, serving as a major drive towards the biogas system incorporation in the hybrid for environmental savings benefits. The analyzed animal wastes data having compiled from diverse sources as applicable to the biogas subsystem component modelling is found in table 2 .

TABLE 2: National animal wastes production and the site's analysed values in 2014 [11-15]

\begin{tabular}{|c|c|c|c|c|c|c|c|}
\hline Item & $\begin{array}{l}\text { National } \\
\text { production } \\
\text { (Million } \\
\text { heads) }\end{array}$ & $\begin{array}{l}\text { Site production on } \\
\text { average (Thousand } \\
\text { heads) }\end{array}$ & $\begin{array}{l}\text { Dry matter } \\
\text { production } \\
(\mathrm{kg} / \text { head/d) }\end{array}$ & $\begin{array}{l}\text { National dry } \\
\text { matter production } \\
(\mathrm{kg} / \mathrm{yr} .)\end{array}$ & $\begin{array}{l}\text { Site's dry matter } \\
\text { production } \\
\text { average }(\mathrm{kg} / \mathrm{yr} .)\end{array}$ & $\begin{array}{ll}\text { Carbon } & \\
\text { content } & \text { on } \\
\text { average } & \text { (U. } \\
\text { analyses } & \end{array}$ & $\begin{array}{l}\text { Biogas potential } \\
\left(\mathrm{m}^{3} / \mathrm{kg} \& \mathrm{~kg} / \mathrm{kg} \text { of }\right. \\
\text { dry matter })\end{array}$ \\
\hline Cattle & 19.54 & 22.97 & 2.860 & $2.04 \times 10^{10}$ & $2.40 \times 10^{7}$ & $22.5 \%$ & $0.20 \& 0.24$ \\
\hline Goat & 72.47 & 85.16 & 0.552 & $1.46 \times 10^{10}$ & $1.72 \times 10^{7}$ & $29.5 \%$ & $0.25 \& 0.30$ \\
\hline Pig & 7.07 & 8.30 & 0.661 & $1.71 \times 10^{9}$ & $2.00 \times 10^{6}$ & $40.7 \%$ & $0.56 \& 0.67$ \\
\hline Sheep & 41.33 & 48.56 & 0.329 & $4.96 \times 10^{9}$ & $5.83 \times 10^{6}$ & $31.4 \%$ & $0.25 \& 0.30$ \\
\hline Chicken & 144.95 & 170.33 & 0.043 & $2.28 \times 10^{9}$ & $2.67 \times 10^{6}$ & $32.6 \%$ & $0.28 \& 0.34$ \\
\hline Horse & 0.11 & 0.13 & 3.3 & $1.30 \times 10^{8}$ & $1.54 \times 10^{5}$ & $41.5 \%$ & $0.30 \& 0.36$ \\
\hline Total & 285.46 & 335.45 & N/A & $2.04 \times 10^{10}$ & $5.22 \times 10^{7}$ & N/A & N/A \\
\hline
\end{tabular}

- Density of clean biogas at stp is in the range $1.1-1.5 \mathrm{~kg} / \mathrm{m}^{3}$ [16], with $1.2 \mathrm{~kg} / \mathrm{m}^{3}$ used for further data evaluations in the table 5

\section{LOAD DEMAND ASSESSMENT}

The hybrid power system design major target was in addressing the energy need of the Maiduguri site having specified earlier on. This would be based on a standalone $\mathrm{PV} /$ biogas hybrid system in line with domestic energy need. So far, a single household has been analyzed based on a number of appliances used as well as the duration of usage. On average, 6 persons were considered on the load sizing for the household. This was used in extrapolating to 50 households in the study location, which is equivalent to supplying energy to 1200 persons in the site. It is also noted that the households' energy consumption and even beyond are seasonal dependent based on seasonal experiences of sites under consideration. Regarding this study site, with the described weather pattern, the 2 seasonal experiences were applied in appliances usage adjustment and switching as consumption in the summer (wet season) differs from that of winter (dry season). Hence, this makes the design more realistic, where the load demand was specified for both the summer and the winter seasons for the sizing of the energy system components. Figure 4 summarizes the load profiles. Further random variability was also considered in line, for more realistic design as depicted in table 3.
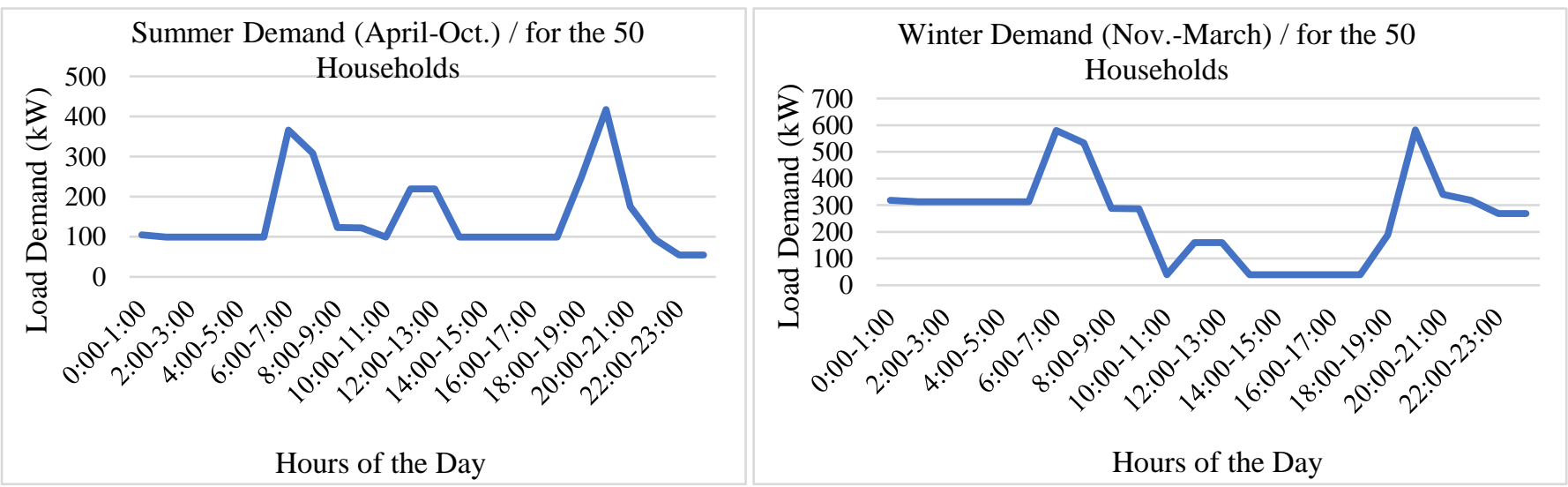

Fig. 4. Load profile for the study location during summer and winter 
TABLE 3: Supplementary load demand specifications

\begin{tabular}{lcc}
\hline \multicolumn{2}{c}{ Random variability assumption for scaling: day to day $=15 \%$, time step to time step $=20 \%$} \\
\hline Parameter & Baseline data (no random variability) & Scaled data \\
Average energy demand $(\mathrm{kWh} / \mathrm{day})$ & 4633 & 4633 \\
Average power demand $(\mathrm{kW})$ & 193 & 193 \\
Peak power demand $(\mathrm{kW})$ & 582 & 1015 \\
Load factor & 0.33 & 0.19 \\
\hline
\end{tabular}

\section{METHODOLOGY}

This research work in fulfilling the assessed load demand of the site has been a modelling approach where solar PV and biomass gasified genset components where considered coupled with electrolyzer for hydrogen generation as a stored secondary energy source. The system architecture has been shown in figure 5 based on the HOMER Pro software application.

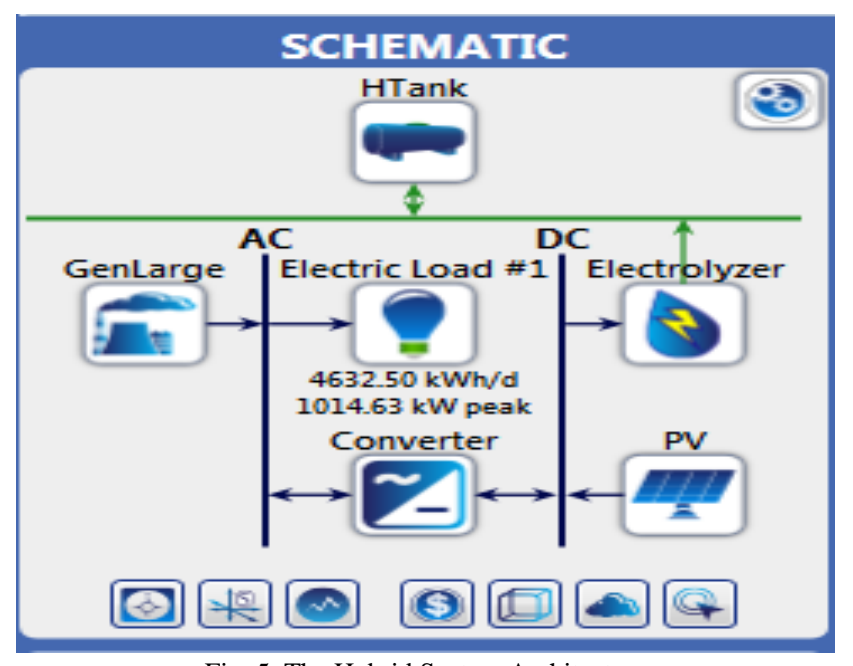

Fig. 5. The Hybrid System Architecture
On the described hybrid system architecture, physical components modelling was done based on different input specifications and sizing, coupled with simulations and optimization in obtaining the optimum configurations in order of economic measures. The input specifications for the different components of the system necessary for the modelling were provided in the succeeding tables in the design input specification part.

Further assessment was done to the simulated and optimized systems for energy efficiency measures. The energy efficiency assessment was a demand side-based, where switching of appliances were done for heating and lighting operations. The lighting operation was switched from the already specified incandescent bulbs in the load calculations to the use of light emitting diode (LED), whereas, the heating aspect was on switching the specified electric cooking and electric water heating to the use of improved biomass cooking stove (IBCS). In all cases, the cost implications of adopting the energy efficiency measures was analyzed and the efficiency multiplier determined as inputs to the assessment with further simulations and optimization. The energy efficiency input analyses table was also brought forth in the design input specification part. The model in figure 6 gives the summary of the HOMER design principle.

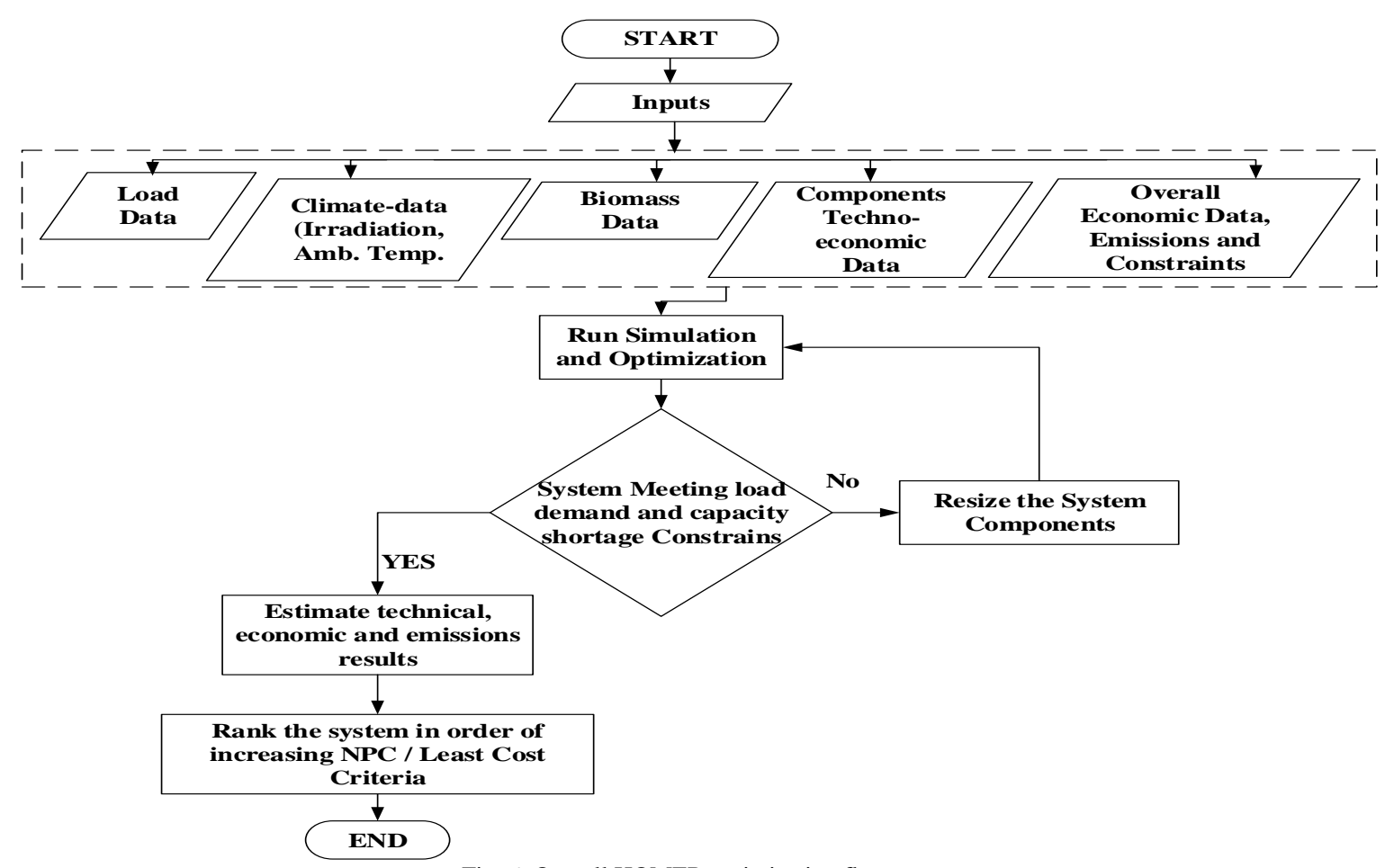

Fig. 6. Overall HOMER optimization flow pattern 
Regarding the operational strategy of the system with strong consideration to hydrogen production as the crucial secondary energy of the system, the energy management has been clearly analyzed as presented in the below figure. Firstly, the power generation of the biogas genset is being optimized to depend on the solar PV component generation of the system. If the generation is insufficient for the load demand, then the genset is automatically switched based on its minimum load ratio, such that excesses in generation from the required load demand necessitates activation of the electrolyzer based on its optimal capacity for the hydrogen production and storage. The management aspect in the system operation has been clearly described in figure 7 .

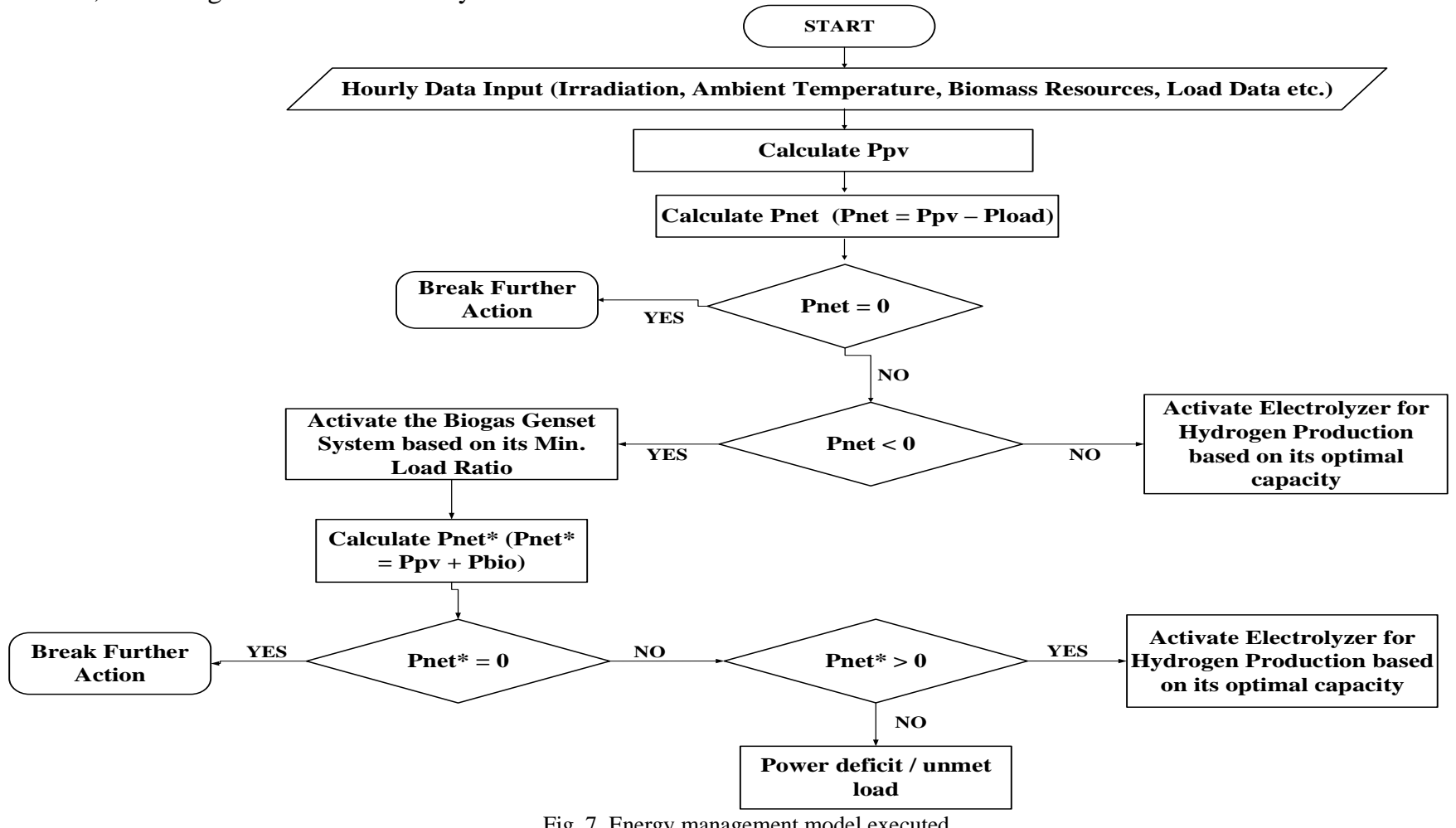

Further economic assessment of the hybrid system with its comparable energy efficiency measure has been done using Microsoft EXCEL, in analyzing the benefits associated with the switching to the energy efficiency-based system operation. This has been based on different economic parameters viz.: simple payback period (PBP), discounted payback period (DPBP), rate of return (ROR), and internal rate of return (IRR) of such saved cash benefits in the transition process.

Finally, was the concise qualitative assessment of the produced secondary energy, which is the hydrogen based on some sustainability measures, coupled with quantitative evaluations of its penetration in a transport sector as an example.

The input specifications for the overall hybrid system modelling has been ensured with all its analyses where necessary. Real interest rate or discount rate of the whole system has been assumed to be $6 \%$, and the project life being 25 years. The operating reserve which has a direct impact on the capacity shortage has been set at $10 \%$ of hourly load. The other necessary specifications for the system components were given in the appendices section i.e. Appendix A, B, and C.

\section{RESULTS AND DISCUSSIONS}

The results of the adopted design methodology with all the necessary and sufficient input specifications have been successful for the system and its comparable energy efficiency measures as discussed next.

\section{- Optimization results of the hybrid system}

The optimization results being based on single objective function that minimizes NPC (i.e. Least Cost Ranking Order) for the different feasible configurations have been highlighted in the table 4.

TABLE 4. Categorized optimization results for the hybrid system

\begin{tabular}{|c|c|c|c|c|c|c|c|c|c|}
\hline \multicolumn{4}{|c|}{ Architecture } & \multicolumn{4}{|c|}{ Costs } & \multicolumn{2}{|c|}{ System } \\
\hline PV & Bio-genset & Electrolyzer & Converter & NPC & LCOE & Capital & Op. Cost & Fuel (t/yr.) & $\mathrm{H}_{2}$ (kg/yr.) \\
\hline & 1000 & & & $\$ 23.8 \mathrm{M}$ & $\$ 1.09 / \mathrm{kWh}$ & $\$ 1.69 \mathrm{M}$ & $\$ 1.71 \mathrm{M}$ & 9543 & 0 \\
\hline & 1000 & 20 & 100 & $\$ 24.0 \mathrm{M}$ & $\$ 1.10 / \mathrm{kWh}$ & $\$ 1.78 \mathrm{M}$ & $\$ 1.72 \mathrm{M}$ & 9543 & 2,713 \\
\hline 100 & 1000 & & 100 & $\$ 24.2 \mathrm{M}$ & $\$ 1.11 / \mathrm{kWh}$ & $\$ 2.08 \mathrm{M}$ & $\$ 1.71 \mathrm{M}$ & 9522 & 0 \\
\hline 100 & 1000 & 20 & 100 & $\$ 24.3 \mathrm{M}$ & $\$ 1.11 / \mathrm{kWh}$ & $\$ 2.10 \mathrm{M}$ & $\$ 1.72 \mathrm{M}$ & 9522 & 2,768 \\
\hline
\end{tabular}


Based on the optimization results showcased, it is evident that the net present costs are in closed range as well as the levelized cost of electricity. The most economically feasible configuration is the one with $1000 \mathrm{~kW}$ bio-genset, with no electrolyzer consideration hence, no hydrogen production. Considering the configuration with the highest hydrogen production is of great interest in this research. This makes going for the feasible configuration having solar PV of

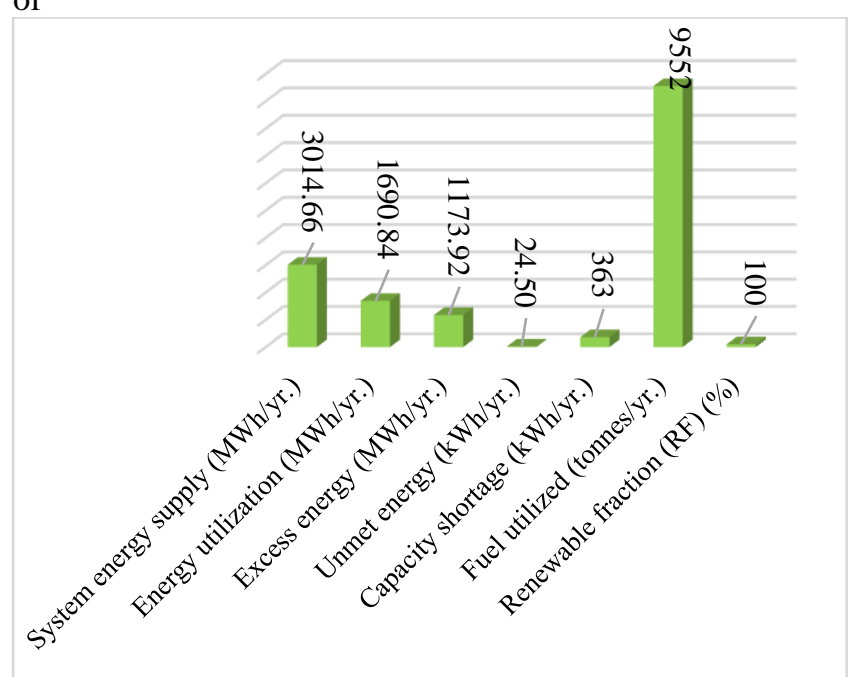

NB: Components energy supply shares (Solar PV: 5.35\%; Bio-genset: $94.65 \%)$

Fig. 8. Technical analyses result for the system

TABLE 5: Supplementary results for the electrolyzer performance and $\mathrm{H}_{2}$ production

\begin{tabular}{lccc}
\hline Input parameters & Specification & $\begin{array}{c}\text { Output } \\
\text { parameters }\end{array}$ & Specification \\
\hline $\begin{array}{l}\text { Maximum power input } \\
(\mathrm{kW})\end{array}$ & 20.00 & $\begin{array}{c}\text { Maximum } \\
\mathrm{H}_{2} \text { output } \\
\text { (kg/hr.) }\end{array}$ & 0.41 \\
$\begin{array}{l}\text { Mean power input } \\
(\mathrm{kW})\end{array}$ & 15.60 & $\begin{array}{c}\text { Mean } \mathrm{H}_{2} \\
\text { output } \\
\text { (kg/hr.) } \\
\text { Total } \mathrm{H}_{2} \\
\text { production } \\
\text { (kg/yr.) }\end{array}$ & 0.32 \\
Capacity factor (\%) & 77.90 & 2,768 \\
$\begin{array}{l}\text { Hours of operation } \\
\text { (Hrs.) }\end{array}$ & 7,260 & & \\
$\begin{array}{l}\text { Total energy input } \\
\text { (MWh/yr.) }\end{array}$ & 136.48 & & \\
\hline
\end{tabular}

Beginning with the technical analyses results for both the overall system and the secondary part of the system for the hydrogen production, the results have been put forward in figure 8 and table 5 . It is evident that the total energy supply of the system happened to be $3,014.7 \mathrm{MWh} / \mathrm{yr}$., where solar PV accounted for $5.35 \%$ and the bio-genset being $94.65 \%$. This led to the utilization of $1,690.8 \mathrm{MWh} / \mathrm{yr}$., with excess generation of $1,173.92 \mathrm{MWh} / \mathrm{yr}$. and an unmet demand of $24.5 \mathrm{kWh} / \mathrm{yr}$. The electrolyzer performance based on its optimal capacity showed a total operating hour of 7,260 with a high capacity factor of about $78 \%$. Based on the total input energy to the electrolyzer, and its efficiency, the hydrogen production has been cumulatively $2,768 \mathrm{~kg}$ in the whole year simulation. This could be considered amazing considering the minimal unmet energy observed, showing demand being met most of the hours in the year with further excesses of energy. The technical analyses ultimately led to
$100 \mathrm{~kW}, 1000 \mathrm{~kW}$ bio-genset, 20kW electrolyzer, and 100kW of solar PV converter with total hydrogen production of $2,768 \mathrm{~kg} / \mathrm{yr}$. maximum.

Further results and discussion of the optimum configuration with this hydrogen production followed with respect to the technical assessments, economic assessment, and lastly the emission assessment followed.

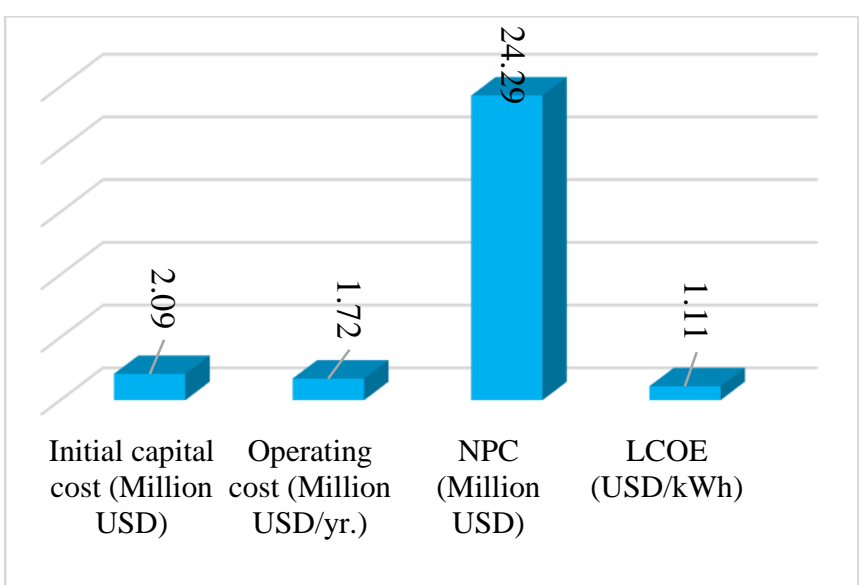

Fig. 9. Economic analyses result of the system

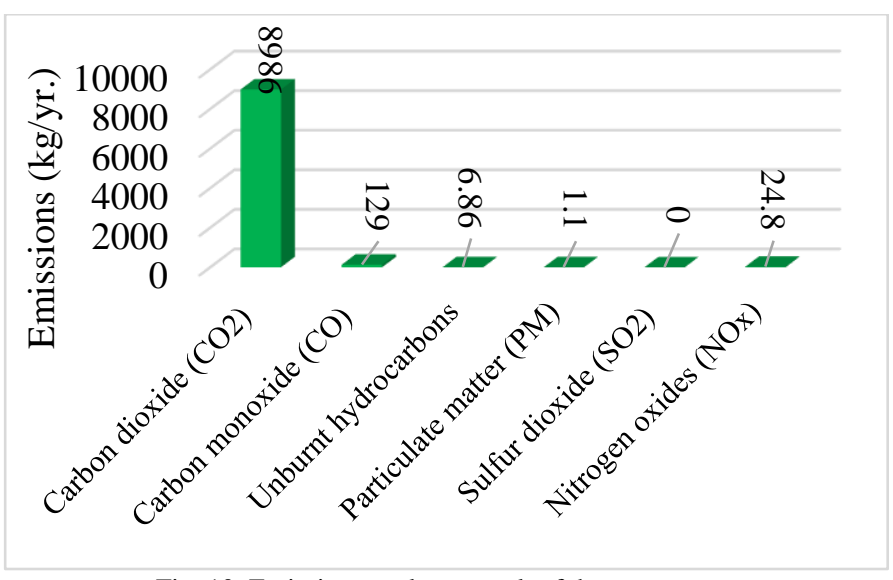

Fig. 10. Emissions analyses result of the system

the system economics having showcased in figure 9. It showed clearly a net present value of the system being around \$24 million leading to a levelized electricity cost of $\$ 1.11 / \mathrm{kWh}$, all based

on the estimated initial cost of about \$2 million and an annualized operating cost of below two million dollars.

On moving to the emissions evaluation aspect having presented in figure 10, the central focus is the $\mathrm{CO}_{2}$ emission as a greenhouse gas responsible for global warming. The value obtained is closed to $9000 \mathrm{~kg} / \mathrm{yr}$. This value is considered as direct emissions from the system, and principally from the biogas genset component, where biogas is burnt for the energy generation. This value tends to be neutral in the long run, i.e. on life cycle basis, basing on the argument that biomass is carbon neutral. The solar PV 
component of the system has no any contributions to this effect as its direct emission is zero.

\section{- Results of Energy Efficiency (EE) measures to the hybrid system}

The results of the applied energy efficiency measures to the standalone hybrid system with further focus on the hydrogen generation has also been successful with the optimization results of its different feasible configurations in table 6.

TABLE 6. Categorized optimization results for the hybrid system with EE measures

\begin{tabular}{|c|c|c|c|c|c|c|c|c|c|}
\hline \multicolumn{4}{|c|}{ Architecture } & \multicolumn{4}{|c|}{ Costs } & \multicolumn{2}{|c|}{ System } \\
\hline $\mathrm{PV}$ & Bio-genset & Electrolyzer & Converter & NPC & $\mathrm{LCOE}$ & Capital & Op. Cost & Fuel (t/yr.) & $\mathrm{H}_{2}$ (kg/yr.) \\
\hline & 600 & & & $\$ 14.3 \mathrm{M}$ & $\$ 1.17 / \mathrm{kWh}$ & $\$ 1.01 \mathrm{M}$ & $\$ 1.03 \mathrm{M}$ & 5662 & 0 \\
\hline & 600 & 20 & 100 & $\$ 14.4 \mathrm{M}$ & $\$ 1.18 / \mathrm{kWh}$ & $\$ 1.11 \mathrm{M}$ & $\$ 1.03 \mathrm{M}$ & 5662 & 2,783 \\
\hline 300 & 600 & & 100 & $\$ 14.7 \mathrm{M}$ & $\$ 1.20 / \mathrm{kWh}$ & $\$ 2.04 \mathrm{M}$ & $\$ 0.98 \mathrm{M}$ & 5362 & 0 \\
\hline 300 & 600 & 20 & 100 & $\$ 14.8 M$ & $\$ 1.21 / \mathrm{kWh}$ & $\$ 2.06 \mathrm{M}$ & $\$ 0.98 M$ & 5362 & 2,902 \\
\hline
\end{tabular}

Similar to the previous system without the energy efficiency, it is obvious that the optimized configurations have got closed NPC and LCOE values. Although the least cost system is obviously without PV component, converter, and electrolyzer hence, hydrogen production is not favored. However, looking at the closed NPC values, the optimum configuration with maximum hydrogen production being of interest has got $300 \mathrm{~kW}$ solar PV, $600 \mathrm{~kW}$ bio-genset, $20 \mathrm{~kW}$ electrolyzer, and $100 \mathrm{~kW}$ inverter. The configuration favored

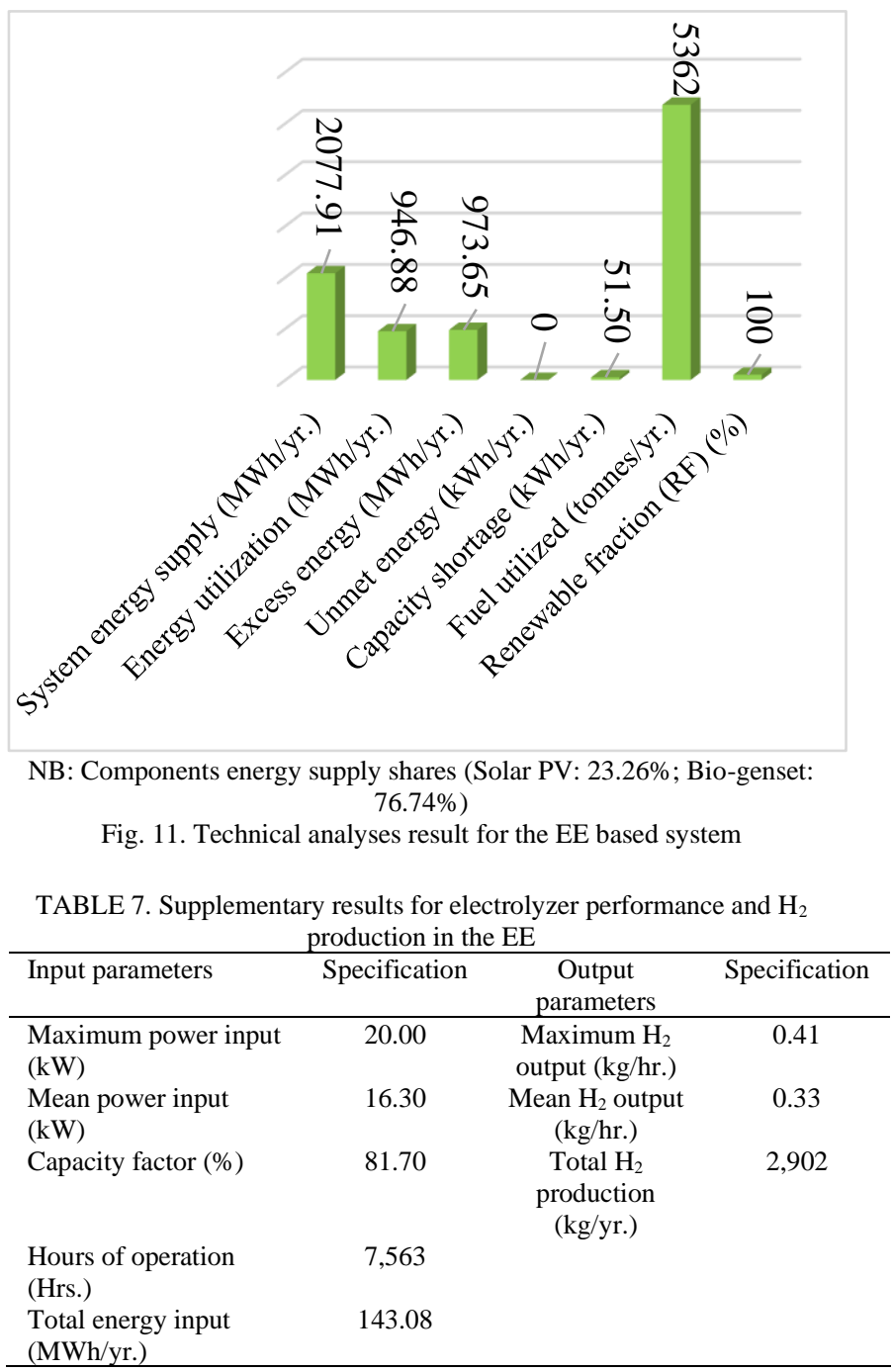

solar PV component with a capacity increase but lowered the bio-genset system, however, a reduction in overall system capacity as compared to the initial system without the EE measures. This resulted from the load demand cut-down arising from the energy efficiency multiplier input. Further assessment for the in-depth performance of the selected system with respect to the technical, economic and emissions analyses followed.

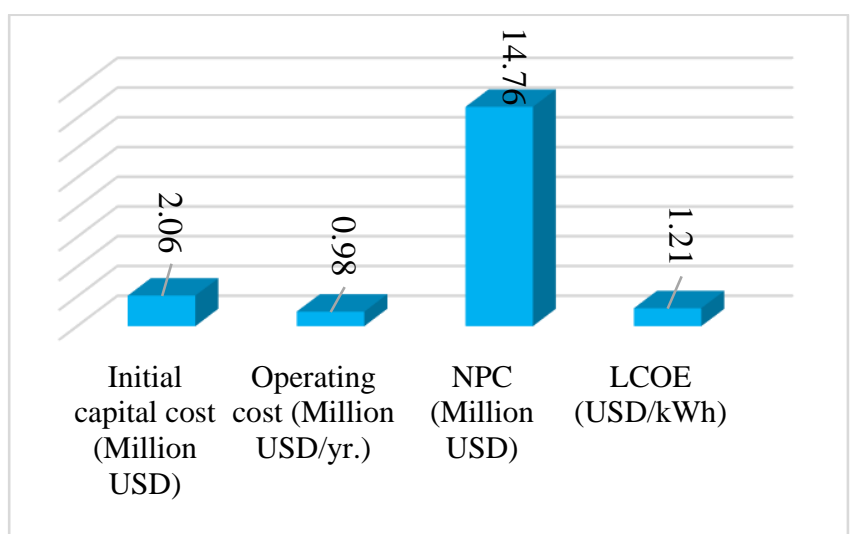

Fig. 12. Economic analyses result for the EE-based system

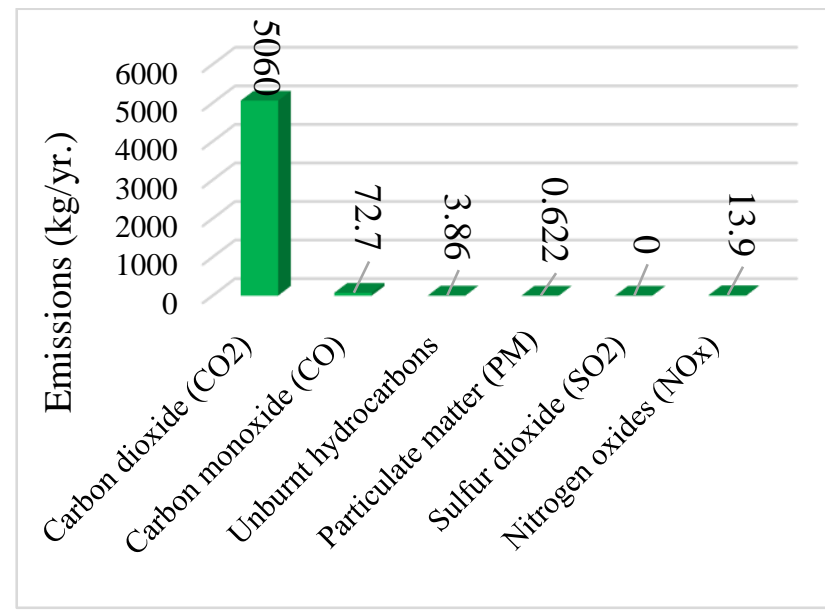

Fig. 13. Emissions analyses result for the EE-based System

Regarding the technical in-depth analyses of figure 11, and its supplementary part in table 7 , it is evident that the switch from the initial system to its energy efficiency measure resulted in about $31 \%$ reduction in system energy supply, $44 \%$ reduction in load energy utilization, $17 \%$ 
reduction in excess energy in the whole system operation and intervention measures, with ultimately around 5\% increase in hydrogen production. Furthermore, this has also affected the system economics having seen in figure 12 , where a reduction is obvious by $39 \%$ in the NPC, although with a slight and negligible increase in the LCOE owing to the load energy utilization patterns inconsistent with the costing evaluations in both systems. The emission of $\mathrm{CO}_{2}$ has also been lowered significantly in the EE-base system to around $44 \%$ due to the capacity of the genset lowering in the new optimization as well as the ultimate reduction in fuel consumption.

\section{- Supplementary economic benefit assessment of the system switching}

These analyses having conducted by Microsoft EXCEL has been a drive towards seeing the implication of the saved amount of money on the switch to the adoption of the energy efficiency measures on the standalone hybrid system. It is evident from the result having showcased in table 8 based on the applied discount factors, the capital recovery factor, and the life span of the project in the annuity analyses that the saved amount of money could recover back the total costs of the energy efficiency-based system within 19 years of the project life cycle. However, on discounting the annualized benefits in the analyses, it is obvious that the discounted payback period (DPBP) could not be realized. This is due to the time value of money considerations that resulted in lowering the annualized benefits, making them insufficient in paying back the total costs in the project at the defined life span. Further analyses on the system switch over gave a return on investment of $5 \%$ and an internal rate of return of $2 \%$.

TABLE 8. Benefits analyses of the switch to the EE-based system (Excel results)

\begin{tabular}{lc}
\hline Analyzed parameters & Specification \\
\hline Calculated Capital Recovery Factor (CRF) & 0.0782 \\
Net of NPC as benefit of the system switch to EE-based system & $\$ 95.26 \mathrm{M}$ \\
Calculated annualized value of the benefit & $\$ 745.20 \mathrm{k}$ \\
Calculated Payback Period (PBP) & 19.81 years \\
Discounted Payback Period (DPBP) & Not Achievable \\
Calculated Rate of Return (ROI) & $5.05 \%$ \\
Calculated Internal Rate of Return (IRR) & $2 \%$ \\
\hline
\end{tabular}

\section{- The hydrogen potential impact assessment}

Hydrogen is predicted to be the future of Africa in energy applications hence, a fundamental requirement in the energy transition. This is due to its outstanding technical features such as being of highest calorific value than any other conventional fuel, and also very light, and the lightest of all gases making it easily transported. On environmental perspective, this fuel is considered as a clean energy source with zero emissions to the atmosphere nor any other environmental negative consequences. The fuel could be applied in many developmental sectors as a breakthrough, such as the industrial sectors, agricultural sector, further power production, transport sector and so on. In quantitative terms however, the assessment is focusing solely on one of the development sectors i.e. the transport sector for the technical and environmental advantages of the generated hydrogen in the modelling and optimization work done while comparing to other conventional fuels applied in the sector. In the sector, the most conventionally used fuels in road transport have been the gasoline and diesel. The comparative analysis has been summarised in table 9 .

TABLE 9. The transport sector hydrogen benefit analyses summary

\begin{tabular}{|c|c|c|c|}
\hline \multicolumn{2}{|c|}{$\begin{array}{l}\text { Hydrogen production in the proposed optimized system scenario } \\
(2,768 \mathrm{~kg} / \mathrm{yr} \text {. })\end{array}$} & \multicolumn{2}{|c|}{$\begin{array}{l}\text { Hydrogen production in the optimized proposed system with EE } \\
\text { measures }(2,902 \mathrm{~kg} / \mathrm{yr} \text {. })\end{array}$} \\
\hline Fuels & Specifications & Fuels & Specification \\
\hline The $\mathrm{H}_{2}$ in Internal Combustion & Energy input: 393.06GJ & The $\mathrm{H}_{2}$ in Internal Combustion & Energy input: 412.08GJ \\
\hline Engines (ICEs) applications & Electricity output: 204.39GJ & Engines (ICEs) applications & Electricity output: $214.28 \mathrm{GJ}$ \\
\hline $\begin{array}{l}\text { The } \mathrm{H}_{2} \text { in fuel-cells electric } \\
\text { vehicles applications }\end{array}$ & $\begin{array}{l}\text { Energy input: } 393.06 \mathrm{GJ} \\
\text { Electricity output: } 196.53 \mathrm{GJ}\end{array}$ & $\begin{array}{l}\text { The } \mathrm{H}_{2} \text { in fuel-cells electric } \\
\text { vehicles applications }\end{array}$ & $\begin{array}{l}\text { Energy input: } 412.08 \mathrm{GJ} \\
\text { Electricity output: } 206.04 \mathrm{GJ}\end{array}$ \\
\hline $\begin{array}{l}\text { Comparable diesel in ICEs in } \\
\text { view of same electricity output as } \\
\mathrm{H}_{2} \text { in ICEs }\end{array}$ & $\begin{array}{l}\text { Equivalent energy input: } \\
\text { 1021.95GJ } \\
\text { Electricity output: } 204.39 \mathrm{GJ}\end{array}$ & $\begin{array}{l}\text { Comparable diesel in ICEs in } \\
\text { view of same electricity output } \\
\text { as } \mathrm{H}_{2} \text { in ICEs }\end{array}$ & $\begin{array}{l}\text { Equivalent energy input: } \\
\text { 1071.40GJ } \\
\text { Electricity output: } 214.28 \mathrm{GJ}\end{array}$ \\
\hline $\begin{array}{l}\text { Comparable diesel in ICEs in } \\
\text { view of same electricity output as } \\
\mathrm{H}_{2} \text { in fuel-cells electric vehicles }\end{array}$ & $\begin{array}{l}\text { Equivalent energy input: } \\
\text { 982.65GJ } \\
\text { Electricity output: } 196.53 \mathrm{GJ}\end{array}$ & $\begin{array}{l}\text { Comparable diesel in ICEs in } \\
\text { view of same electricity output } \\
\text { as } \mathrm{H}_{2} \text { in fuel-cells electric } \\
\text { vehicles }\end{array}$ & $\begin{array}{l}\text { Equivalent energy input: } \\
\text { 1030.20GJ } \\
\text { Electricity output: } 206.04 \mathrm{GJ}\end{array}$ \\
\hline $\begin{array}{l}\text { Comparable gasoline in ICEs in } \\
\text { view of same electricity output as } \\
\mathrm{H}_{2} \text { in ICEs }\end{array}$ & $\begin{array}{l}\text { Equivalent energy input: } \\
\text { 1362.60GJ } \\
\text { Electricity output: } 204.39 \mathrm{GJ}\end{array}$ & $\begin{array}{l}\text { Comparable gasoline in ICEs in } \\
\text { view of same electricity output } \\
\text { as } \mathrm{H}_{2} \text { in ICEs }\end{array}$ & $\begin{array}{l}\text { Equivalent energy input: } \\
\text { 1428.53GJ } \\
\text { Electricity output: } 214.28 \mathrm{GJ}\end{array}$ \\
\hline $\begin{array}{l}\text { Comparable gasoline in ICEs in } \\
\text { view of same electricity output as } \\
\mathrm{H}_{2} \text { in fuel-cells electric vehicles }\end{array}$ & $\begin{array}{l}\text { Equivalent energy input: } \\
\text { 1310.2GJ } \\
\text { Electricity output: } 196.53 \mathrm{GJ}\end{array}$ & $\begin{array}{l}\text { Comparable gasoline in ICEs in } \\
\text { view of same electricity output } \\
\text { as } \mathrm{H}_{2} \text { in fuel-cells electric } \\
\text { vehicles }\end{array}$ & $\begin{array}{l}\text { Equivalent energy input: } \\
\text { 1373.6GJ } \\
\text { Electricity output: } 206.04 \mathrm{GJ}\end{array}$ \\
\hline \multicolumn{2}{|c|}{$\begin{array}{l}\text { - Calculated emissions savings from diesel ICEs to the } \mathrm{H}_{2} \text { in ICEs } \\
\text { application: 73.80tonnes of } \mathrm{CO}_{2} / \mathrm{yr} \text {. } \\
\text { - Calculated emissions savings from diesel ICEs to the } \mathrm{H}_{2} \text { in fuel- } \\
\text { cells application: 70.96tonnes } \mathrm{CO}_{2} / \mathrm{yr} \text {. }\end{array}$} & \multicolumn{2}{|c|}{$\begin{array}{l}\text { - Calculated emissions savings from diesel ICEs to the } \mathrm{H}_{2} \text { in ICEs or } \\
\text { fuel-cell application: 77.36tonnes of } \mathrm{CO}_{2} / \mathrm{yr} \text {. } \\
\text { Calculated emissions savings from diesel ICEs to the } \mathrm{H}_{2} \text { in fuel- } \\
\text { cells application: } 74.39 \text { tonnes } \mathrm{CO}_{2} / \mathrm{yr} \text {. }\end{array}$} \\
\hline
\end{tabular}


- Calculated emissions savings from gasoline ICEs to the $\mathrm{H}_{2}$ in ICEs or fuel-cells: 96.09tonnes of $\mathrm{CO}_{2} / \mathrm{yr}$.

- Calculated emissions savings from gasoline ICEs to the $\mathrm{H}_{2}$ in fuel-cells application: 92.39tonnes $\mathrm{CO}_{2} / \mathrm{yr}$.
Calculated emissions savings from gasoline ICEs to the $\mathrm{H}_{2}$ in ICEs or fuel-cells: 100.74 tonnes of $\mathrm{CO}_{2} / \mathrm{yr}$

Calculated emissions savings from gasoline ICEs to the $\mathrm{H}_{2}$ in fuelcells application: 96.87 tonnes

\{Data applied: Electrical efficiency of $\mathrm{H}_{2} \mathrm{ICE}=52 \%$ [17]; specific energy of $\mathrm{H}_{2}=142 \mathrm{MJ} / \mathrm{kg}$ [18]; electrical efficiency of Fuel-cell = 50\% [19]; electrical efficiency of diesel ICE $=20 \%$ [20]; electrical efficiency of gasoline ICE $=15 \%$ [20]; emission factor of $\mathrm{H}_{2}=0$; emission factor of gasoline (mobile combustion) = 8.78kg $\mathrm{CO}_{2} /$ gallon [21]; emission factor of diesel (mobile combustion) $=10.21 \mathrm{~kg} \mathrm{CO} /$ gallon [21]; density of gasoline $=715 \mathrm{~kg} / \mathrm{m}^{3}[22] ;$ density of diesel $=830 \mathrm{~kg} / \mathrm{m}^{3}$ [23]; specific energy of gasoline $=46 \mathrm{MJ} / \mathrm{kg}[24]$; specific energy of diesel $=45 \mathrm{MJ} / \mathrm{kg}[24]$ \}

Based on the summarized findings on the benefit assessment of the hydrogen production, it appeared as to how the energy consumptions could be lowered significantly for same final energy output in favour of the hydrogen integration for the ICE and the fuel-cell electric vehicles cases. This is owing to the efficient nature of the hydrogen fuel having seen from the input data of the comparative analyses. It is also important to stress on the fact that the energy efficiency-based results have got more benefits with regards to improved final energy services all through due to increased generations of the hydrogen in that regard. Regarding the emissions savings, it could be seen that adopting the hybrid system and applying the produced hydrogen in substitute of diesel fuels for automobiles with regards to same internal combustion engine applications resulted in 73.8tonnes of $\mathrm{CO}_{2}$ avoided whereas; as substitute to the gasoline fuel yielded 96tonnes of $\mathrm{CO}_{2}$ avoided. These have been seen to differ from the case of the hydrogen applications to fuel-cell electric vehicles, of which the transition to such clean energy from the conventional diesel and gasoline applications resulted in 70.96tonnes $\mathrm{CO}_{2} / \mathrm{yr}$. and 92.39tonnes $\mathrm{CO}_{2} / \mathrm{yr}$. avoided emissions respectively. The decrement in the avoided emissions on the case of the fuel-cell-based applications has been due to the conversion efficiency slight gap in the two potential applications of the hydrogen fuel as obtained from the literature. In all the cases, values could be seen to increase on the energy efficiency-based system. This increment was by around 5\% for both the diesel and gasoline switch over to the hydrogen ICEs and the hydrogen fuel-cells electric vehicles applications.

\section{CONCLUSION}

Concise modelling and optimization of standalone solar PV/biogas hybrid system with hydrogen storage has been conducted for a specific site of Maiduguri, in Northern Nigeria for domestic energy need. A combination of HOMER software and Microsoft Excel were applied in the different techno-economic and emissions analyses as well as energy efficiency assessment to the standalone system as a potential opportunity area.

The considered optimized system configuration based on maximum hydrogen production has got $100 \mathrm{~kW}$ solar PV component, $1000 \mathrm{~kW}$ biogas genset, $100 \mathrm{~kW}$ inverter, with an electrolyzer of $20 \mathrm{~kW}$, for addressing the energy need of a defined load profile of the site. This configuration resulted in a total annual energy production of $3,014.66 \mathrm{MWh}$, that was found to be $31 \%$ less than the system with the energy efficiency measures, which has ultimately reflected also the load energy consumption all due to the efficiency multiplier impact to the load demand. The economics of the system also has showed a tremendous decrease in NPC in favour of the energy efficiency-based system as well as massive reduction in the operational level greenhouse gas emission being a strong concern in line with sustainability. Further economic benefit analyses in comparing the standalone system and its energy efficiency-based system showed the extent of the saved amount of money in the switch over regarding different economic benefit parameters.

The hydrogen production in both systems of which more production has been observed in the energy efficiencybased system could be strongly relevant and a breakthrough in different sectors of development. An example being the analysed transport sector in the potential impact assessment with the observed technical advantages and emissions savings of the diesel and gasoline conventional fuels substitute.

These in overall could be seen as the significance of developing and expanding the applications of such energy solutions with impacts in more than one sector of development, not only in the case study country but the African continent and beyond. This is in view of the strong need for a sustainable energy supply at all levels.

\section{ACKNOWLEDGMENT}

This study was carried out under the project "Water and Energy Security in Africa (WESA), financially supported through the German Federal Ministry of Education and Research (BMBF)

\section{REFERENCES}

[1] S. Negi and L. Mathew, "Hybrid Renewable Energy System: A Review," International Journal of Electronic and Electrical Engineering, vol. 7, p. 08, 2014.

[2] International Energy Agency (IEA), "African Energy Outlook: A Focus on the Energy Prospects in Sub-Saharan Africa," InternationalEnergyAgency, Paris, France, 2014.

[3] T. Douglas, "Dynamic modelling and simulation of a solar-PV hybrid battery and Hydrogen Energy System," Journal of Energy Storage: Available at Science Direct, p. 11, 2016.

[4] Z. Abdin and W. Merida, "Hybrid energy systems for off-grid power supply and hydrogen production based on renewable energy: A techno-economic analysis," Energy Conversion and Management, p. $12,2019$.

[5] M. R. Barakat, B. Tala-ighil, H. Gualous and D. Hissel, "Modeling of a hybrid marine current-hydrogen active power generation," International Journal of Hydrogen Energy, p. 15, 2018.

[6] D. Groppi, D. A. Garcia, L. G. Basso, F. Cumo and D. L. Santolli, "Analysing economic and environmental sustainability related to the use of battery and hydrogen energy storages for increasing the energy independence of small islands," Energy Conversion and Management, p. 13, 2018

[7] SpainExhcange.com, "Weather and Climate in Nigeria," 2019 [Online]. Available: https://www.studycountry.com/guide/NGclimate.htm. [Accessed July 2019]. 
[8] worldatlas.com, "Where is Maiduguri, Nigeria," 2019. [Online]. Available: $\quad$ https://www.worldatlas.com/af/ng/bo/where-ismaiduguri.html. [Accessed July 2019].

[9] Cedar lake ventures, "Average Weather in Maduguri," n.d. [Online]. Available: https://weatherspark.com/y/74227/Average-Weather-inMaiduguri-Nigeria-Year-Round. [Accessed July 2019].

[10] National Aeronautics Space Administration (NASA), "Surface Meteorology and Solar Energy," n.d. [Online]. Available: https://eosweb.larc.nasa.gov/sse/RETScreen/. [Accessed October 2017].

[11] Food and Agricultural Organization (FAO), "Crops Data," 2017 [Online]. Available: http://www.fao.org/faostat/en/\#data.

[12] K. Simonya and O. Fasina, "Biomass Resources and Bioenergy Potentials in Nigeria," African Journal of Agricultural Research, vol. vol. 8, p. 15, 2013

[13] United Nations Environmental Program (UNEP), "Technologies for Converting Waste Agricultural Biomass to Energy," United Nations Environmental Program (UNEP), Osaka, Japan, 2013

[14] D. Paul, F. Nicolae and F. Matei, "Main factors affecting biogas production - an overview," Romanian Biotechnological Letters Journal, vol. Vol. 19, p. 14, 2014.

[15] R. Moral , J. Moreno and M. Perez, "Characterisation of the organic matter pool in manures," Journal of Bioresource Technology: Available at Science Direct, p. 6, 2004

[16] D. Ludington, "Biogas Heating Value Calculations," n.pub, n.d.

[17] M. N. A. Mohammed and N. Yamada, "Efficiency Analyses of Automotive Hydrogen Internal Combustion Engine Combined with a Steam Rankine Cycle," nPub., 2010.

[18] P. J. Rodrigue, "Energy Contents of some Combustibles," 2019. [Online]. Available: https://transportgeography.org/?page_id=5837. [Accessed July 2019].

[19] Independent Energy, "Energy Efficiency," 2019. [Online]. [Accessed July 2019]
[20] S. Furfari, "Energy efficiency of engines and appliances for transport on land, water, and in air," AMBIO, vol. 45, p. 6, 2015.

[21] Environmental Protection Agency (EPA), "Emission Factors for Greenhouse Gas Inventories," 2014

[22] EngineeringToolbox, 2003. [Online]. Available: https://www.engineeringtoolbox.com/fuels-higher-calorific-valuesd_169.html. [Accessed July 2019].

[23] NativeDynamics, "Specific Energy and ENergy Density of Fuels," 2019. [Online]. Available: https://neutrium.net/properties/specificenergy-and-energy-density-of-fuels/. [Accessed July 2019].

[24] J. Hanania, B. Heffernan, J. Jenden, R. Leeson, T. Mah and J. Martin, "Energy Density," 2018. [Online]. Available: https://energyeducation.ca/encyclopedia/Energy_density. [Accessed July 2019]

[25] A. Muyiwa, D. Quansah, C. M. Agelin and S. S. Paul, "Multipurpose renewable energy resources based hybrid energy system for remote community in Northern Ghana," Journal of Sustainable Energy Technology and Assessment, p. 10, 2017.

[26] S. Sara, P. Rita, A. Malmquist and A. Pina, "Feasibility study of using a biogas engine as backup in a decentralized hybrid (PV/Wind/Battery) Power Generation System: Case Study of Kenya," Journal of Energy: Available at Science Direct, p. 12, 2015.

[27] Cat-ElectricPower, "Gas Generator Set: AG Biogas," n.Pub., 2011.

[28] Common Wealth of Australia, "Emissions Estimation Manual Technique for Combustion Engines," National Population Inventory, 2008.

[29] U. Davis, "Revised Air Quality and Greenhouse Gas Emissions Calculations," 2012.

[30] International Energy Agency (IEA), "Technology Roadmap Hydrogen and Fuel Cells," International Energy Agency, France, 2015 .

\section{- APPENDICES}

Appendix A. Input specifications for the system components

\begin{tabular}{|c|c|c|c|c|}
\hline Components & Costs & Life span & Sizes used & Others \\
\hline $\begin{array}{l}\text { PV panel (Q- } \\
\text { Cell } 225 \text { / } \\
\text { Polycrystalline) }\end{array}$ & $\begin{array}{l}\text { C.C: } 3,000 \$ / \mathrm{kW} ; \text { R.C: } 3,000 \$ / \mathrm{kW} ; \\
\text { O\&M: } 10 \$ / \mathrm{kW} /[25] .\end{array}$ & 25 years & $\begin{array}{l}0,100,150,200,300,400, \\
500,750, \& 1000 \mathrm{~kW}\end{array}$ & $\begin{array}{l}\text { Efficiency @ STC: } 15.3 \% \text {; Nom. op. cell } \\
\text { temp.: } 45^{\circ} \text { C; Temp. Coefficient of power: } \\
0.42 \% / /^{\circ} \text {; Derating F.: } 80 \% \text {; Ground Ref. } \\
20 \% . /[25] \text {. }\end{array}$ \\
\hline $\begin{array}{l}\text { Biogas power } \\
\text { genset }\end{array}$ & $\begin{array}{l}\text { C.C: 1685.4\$/unit; R.C: } \\
\text { 1348.32\$/unit; O\&M: 0.11\$/unit } \\
\text { (Composite of the biodigester and } \\
\text { the biogas genset: Updated cost of } \\
\text { 2015 @ 6\% I.R) / [26]. }\end{array}$ & $\begin{array}{l}15,000 \\
\text { Hrs }\end{array}$ & $\begin{array}{l}0,400,600,800,1000, \& \\
1500 \mathrm{~kW}\end{array}$ & $\begin{array}{l}\text { Min. Load Ratio: 30; Calculated Biogas } \\
\text { Intercept Coefficient:0.1083kg/hr/kW } \\
\text { Calculated Biogas Slope: } 0.5685 \mathrm{~kg} / \mathrm{hr} / \mathrm{kW}_{\text {ou }} \text { ] } \\
\text { [27]; Emissions }\left(\mathrm{kg} / \mathrm{kg} \text { fuel): } \mathrm{CO}-33, \mathrm{NO}_{\mathrm{x}} \text { - } 6 \text { [ }\right. \\
\text { 6.17, PM - } 0.00068 \text { [28, 29]. / [Optimized } \\
\text { operation]. }\end{array}$ \\
\hline $\begin{array}{l}\text { Electrolyzer } \\
\text { (Alkaline type) }\end{array}$ & $\begin{array}{l}\text { C.C: } 1100 \$ / \text { unit; R.C: } 1100 \$ / \text { unit; } \\
\text { O\&M: 50\$/unit / }[6,30]\end{array}$ & 10 years & $\begin{array}{l}0,20,50,70,100,120, \\
150, \& 200 \mathrm{~kW} .\end{array}$ & $\begin{array}{l}\text { Efficiency: } 80 \% \text {; Minimum Load Ratio: } 0 \% \\
\text { [Optimized operation]. }\end{array}$ \\
\hline $\begin{array}{l}\text { Inverter (Generic } \\
\text { C) }\end{array}$ & $\begin{array}{l}\text { C.C: 700\$/unit; R.C: 700\$/unit; } \\
\text { O\&M: 10\$/unit / [25]. }\end{array}$ & 15 & $\begin{array}{l}0,100,150,200,250,300 \\
400,500,750, \& 1000 \mathrm{~kW}\end{array}$ & $\begin{array}{l}\text { DC-AC efficiency: } 90 \% \text {; AC-DC efficiency: } \\
85 \% \text {; Capacity (Rectifier/inverter): } 100 \% \text {. }\end{array}$ \\
\hline
\end{tabular}

NB: C.C: Capital Cost; R.C: Replacement Cost; O\&M: Operation \& Maintenance Cost; I.R: Interest Rate.

Appendix B. Additional input specification for biogas generator fuel

\begin{tabular}{|c|c|c|}
\hline Parameter & Specification & Remarks / Reference \\
\hline Biomass quantity (tons/day) & 136.58 & Summation of all the considered dry matters below \\
\hline Biomass cost (\$/tons) & 0 & Wastes minimization for environmental benefits \\
\hline Biomass aggregate carbon $\mathrm{C}(\%)$ & 26.34 & Calculated based on the share of each Waste in total \\
\hline Biogas to biomass Ratio on aggregate $(\mathrm{kg} / \mathrm{kg})$ & 0.27 & Calculated based on the share of Biogas Potential of each Waste in the total \\
\hline LHV of biogas (MJ/kg) & 20 & Selected from a range / [16] \\
\hline Biogas' density $\left(\mathrm{kg} / \mathrm{m}^{3}\right)$ & 1.2 & Selected from a range / [16] \\
\hline Biogas' $\mathrm{CO}_{2}$ emission factor $(\mathrm{g} / \mathrm{kWh}$ elec. $)$ & 3.12 & Homer Conventional Setting \\
\hline
\end{tabular}


Appendix C. Energy Efficiency (EE) assessment input specifications

\begin{tabular}{lc} 
& \multicolumn{2}{c}{ Appendix C. Energy Efficiency (EE) assessment input specifications } \\
\hline Parameters & $\$ 7,95$ \\
Calculated total costs of considered appliances in baseline case & $\$ 3,855$ \\
Calculated total costs of appliances as substitute for the EE measure & $\$ 3,060$ \\
Calculated capital cost increment on implementing the EE measure & $51 \%$ \\
Calculated load power reduction on implementing the EE in Summer & $40 \%$ \\
Calculated load power reduction on implementing the EE in winter & $44 \%$ \\
Calculated power reduction based on the seasons' energy weights & $100-44 \%=56 \%$ \\
Energy Efficiency (EE) multiplier input & 25 \\
Energy Efficiency (EE) lifetime input & Years
\end{tabular}

